\title{
Managing Guidance and Counselling Services for Patriotism and Values Re-Orietation among the Students of Colleges of Education in Ankpa Education Zone of Kogi State
}

\author{
Yakubu Hassan', Shaibu Leonard² \\ 1M.Ed, ${ }^{2} \mathrm{Ph} . \mathrm{D}$ \\ ${ }^{1}$ Department of Educational Foundations, Anambra State University, Uli, Anambra, Nigeria \\ 2Department of Educational Foundations, Kogi State University, Anyigba, Nigeria
}

\begin{abstract}
The study investigated managing guidance and counselling services for patriotism and values re-orientation among the students of colleges of education in Ankpa education zone of Kogi state. Two research questions guided the study. The study adopted descriptive research design. A sample of 300 students was randomly selected for the study. Students' Patriotism and Values Adherence Level Parameter (SPLP) and Students Values Adherence Parameter (SVAP) were used as instruments. The data collected were analyzed using mean and standard deviation. The cumulative analysis of mean and standard deviation for research question one shows the calculated values of $\mathbf{3 . 5 6}$ and $\mathbf{0 . 0 5}$ revealing that guidance/counselling services does not influence students' level of patriotism in colleges of education in Ankpa education zone. The cumulative analysis of mean and standard deviation for research question two shows the calculated values of $\mathbf{1 . 7 7}$ and $\mathbf{0 . 1 9}$ revealing that management of guidance/counselling services influence colleges of education students' in the practice of the societal values in Ankpa education zone of Kogi state to a little extent. It was recommended that guidance/counselling services should be given top priority by the stakeholders in education industry to enhance the level of students' patriotism and strict adherence to practices of Nigerian values.
\end{abstract}

\section{Keywords: Management, Guidance. Counselling, Patriotism, Values, values re-orientation, College of Education}

\section{INTRODUCTION}

Management as a body is inevitable in the existence of any organizational setting. It is in management that human resource development, organizational performance and overall development of self and society are found. Despite the paramount position of management in the organization the concept still has no universally acceptable definition. This is because; individuals view management from different perspectives depending on the situation and environment. Adzemba (2006) viewed management to be the activities such as planning, organizing, controlling and coordinating the activities of the social organization for profit making. This conception suggests that management is a process, a sequence of coordination of activities in an organisation, including schools, for the achievement of organizational objectives by the management. Thus, Odiba (2007) defined management as the process by which goals are achieved through collective and co-operative human efforts in a sustainable environment. This means that management is a process that involves the manipulation of goal oriented operations which involves collective and co-operative human efforts. It also involves the development of a sustainable environment where the guidance and counsellors as well as clients can harmoniously operate.

In a harmonious operation, Akpakwu (2008) views management as the co-ordination of all the resources of an organisation through the process of planning, organizing, directing and controlling in order to boost the mutual relationship between guidance counsellors and the clients in schools in order to attain organizational objectives. Akpakwu further opined that management could also mean the guidance or direction of people towards the goals or objectives of an organization. Guidance and counselling services therefore, is a human oriented programme, which is based on helping the individual to define and redefined his goals and aspirations in life pursuits for greater productivity. Modo; Sanni; Uwah and Mogbo (2013) identified three major guidance and counseling programmes which helps students succeed in their educational pursuit. This includes educational, vocational and personal-social services/ programmes. The educational services in guidance and counselling takes care of all issues associated with education as they relate to the physical environment of the school, the structural make up of the school, activities within the school, students in take, students progress, and adaptability within the school (Egbule, 2006). Vocational services assist individuals to choose occupation and prepare them to enter into it and make progress. It also involves services provided by the counsellor to assist students start early enough to plan for proper vocation in terms of their interest, abilities, aptitude and duration of training, sponsors, family and societal needs (Egbule, 2006). While personal-social guidance and counselling services help the students to take care of socio-personal problems relating to personality maladjustments (Ugwuebulem and Igbokwe, 1996). Therefore, to effectively manage these programmes in the school calls for adequate deployment of professionals (counsellors) that have been trained academically to help their beneficiaries achieve maximally in spite of all limitations. Modo and Inaja (2010) have defined the counsellor as one that is professionally trained in the field of counselling to help clients or students who may be in need of such help. Denga (2001) sees the counsellor as manager of a project that manages the client's educational, vocational and personal-social potentials in a way that the individual becomes useful to himself and the society at large. Equally, 
the counsellor needs to acquire wealth of experiences through continuous training and development in order to facilitate/inculcate the spirit of consciousness for patriotism and strict adherence to the practice of societal values into learners (Okobiah and Okorodu, 2006).

The role of guidance and counselling services in the school system cannot be overemphasized. Guidance and counselling services have always played a leading role in terms of child's development and improvement in life. For this reason, guidance and counselling services are indispensable to child's development. According to Modo; Sanni; Uwah and Mogbo (2013) guidance and counselling is one of the educational services that promotes the effectiveness of the educational system for goals attainment and guiding learners through the learning process. This is in line with the goals of educational services as contained in the National Policy of Education (2004) which are to -facilitate the implementation of the educational policy; the attainment of policy goals and the promotion of effectiveness of educational system; and make learning experiences more meaningful for children\|. Okobiah and Okorodudu (2006) highlighted that guidance and counselling is encompassed by activities of relevant services and also processes of helping persons within and outside the school, to achieve their full potentialities in their emotional, moral, social, academic and vocational developments. Esen (1998) says that guidance and counselling is aimed primarily at assisting the receiver to discover his own hidden strengths and ultimately grow in independence and ability to take his own decisions, make choices or adjustments unaided. Furthermore, Nwachuku (2007) summarizes the definition of guidance and counselling as Research on Humanities and Social Sciences as: a systematic and organized educational helping service, professionally given by a professionally trained counsellor or therapists to a learner of any age, within or outside the school walls at appropriate level. The essence according to Pamela et al. (2018) is to assist him understand himself, situation and environment, discover his interests, potentialities and opportunities in life and learn how best to effectively utilize his assets as well as minimize his weaknesses, to live a maximum productive life.

Apart from helping a learner to live maximum productive life, guidance and counselling services can be utilized effectively as coping strategy to inculcate the spirit of consciousness that assisted in enhancement of patriotism and strict adherence to the practice of societal values among youths. Umar (2013) also identified the importance of guidance and counselling services as coping strategy for inculcating the consciousness of patriotism and strict adherence to the practice of societal values among youths as one that involves: helping youths to deal with real life issues that affects their lives and society in general; preparing youths for adulthood; inculcating in youths the spirit of unity, nationality and patriotism; preparing youths for effective adult life that cherishes and promotes harmonious relationship among members of the society so that they will enter into adulthood with skills necessary to prevent conflict peacefully; instilling in youth appropriate values and skills in order to enhance their moral development; equip youths with the knowledge and skills that will help bring about peace through better understanding; and inculcating into youths such value like compassion, integrity, hope, justice, unity, gender fairness, caring for life, sharing, reconciliation and active non-violence.
Literature evidence elsewhere shows that effective management of guidance and counselling services affect students' level of patriotism and their adherence to the practice of societal values. For instance, Renuka (2013) in India established that counselling was effective in solving adjustment difficulties like appetite disturbance, concentration problems and depression that were very common among newly admitted college students. Additional findings confirmed that constructive support from individual counselling had positive effect on academic performance and contributed to positive academic performance. Krieger (2011) in Toronto revealed that in-service training on proactive classroom management was beneficial to teachers since it effected change in student behaviour by reducing behaviour problems. Another study by Nweze and Okolie (2014) in Nigeria revealed that counselling services in schools are instrumental in career decision making as well as their level of patriotism. Additional findings indicated that inadequacy of guidance and counselling resources affects students in career decision making as well as adherence to values of the society. Osakwe (2013) in Nigeria established that guidance and counselling requires adequate funding. Mwangi (2014) established that counselling program built moral uprightness and courage in the learners. Additionally, it led to good value, positive attitude towards self discipline and enhanced change of behaviour. Another separate study by Afande (2015) established that effective management of guidance and counselling services is beneficial to pupils by developing skills in decision making as well as strict adherence to societal values.

Values according to Aishtu and Lucy (2016) imply acceptable standards, ideal ways of doing things and living virtuous life in the society. The researchers went further to explain that values cannot function in a vacuum since there is a need to serve societal purposes. The positive or dominant values that serve different societies along with Nigeria include respect and honour accorded to parents, elders, men and women of honour, love and protection of the family and family name has been the practice in the traditional Nigerians have belief central in life in God as Supreme Being. The researcher further added the following values to include integrity, transparency, responsibility, accountability, equity, fairness, efficiency and effectiveness. These values are experiencing degeneration by the day and the need to rejuvenate them has become inevitable to ensure stability, peaceful co-existence and development in Nigeria.

Value orientation according to Bara'atu (2016) is the principle of right and wrong that are accepted by an individuals or social groups. The re-orientation of value system is conscious development of human resources through ideological appeals, planning, training, productivity and efficiency in achievements through corporate culture.

Re-orientation according to Adeyemi (2016) means repositioning of things the way they ought to be in future. Godiya (2016) sees re-orientation as changing once again a position or attitude related to the situation or circumstances. Godddiya added that re-orientation is the state of being redirected differently, rearrangement or realignment intellectually or emotionally. In this case, re-orientation means readdressing things to their normal state/position especially those things we values. Therefore, values re-reorientation in the opinion of Agu (2016) has to do with readdressing those values which have been thwarted in the 
line as a result of change in behaviour. This researcher added that values re-orientation means going back to the root and re-organizing things the way they used to be. This means that values re-orientation is the reversal of those values that are deteriorating in the society to ensure stability, peaceful co-relationship and development. In order words, values reorientation is the re-teaching of the ideals of Nigerian society to ensure stability, peaceful co-existence and development among the citizenry. Beatrice (2016) sees value reorientation as the process of inculcating good values that can help a nation out of her numerous predicaments which can refocus the nation toward greatness. This means patriotism among the citizens can only be a mirage if values are not properly readdressed in Nigeria. Therefore, to ensure patriotism in Nigeria, values re-orientation through various means especially proper management of guidance and counselling services in schools is inevitable. The functional guidance and counselling services are instrumental to values re-orientation which can bring lasting peace and tranquillity a feature of patriotism in Nigeria if not, there will be continuous corruption, moral decadence, lost of lives and properties which will result to underdevelopment and total lost of patriotism.

Patriotism involves attachment to a country, an entity that includes both the social group and the existing norms and institutions which are the foundation for the existing state. Patriotism implies a civic attachment and does assume the existence of a state. Political theorist George Kateb defines patriotism as "a readiness to die and kill for an abstraction: nothing you can see all of, or feel as you feel in the presence of another person, or comprehend," as " a readiness to die and to kill for what is largely a figment of the imagination" (Kateb, 2006). Patriotism is conceptualized as love of country and attachment to national values that is based on critical understanding. The researcher added that patriotism involves making loyalty to the country/government contingent on certain standards of performance, leading people "to stand up against the actions of the group that they see as a betrayal of its basic values, or of basic human values, or as contrary to the group's interests in the long run." Staub (1997) stated that patriotism requires balancing attachment to a consideration for the well-being of one's group with an inclusive orientation to human beings, with respect for the rights and welfare of all people. Patriotism from the above views mean decision to serve the country with love, strength and faith, to passionately serve the country wholeheartedly and mightily, to remain faithful, loyal and honest to the ideals of a country, to defend the unity of a country by the citizens and to uphold the honour and glory of the country of either his residence or origin. The practice of patriotism by Nigerians generally and college of education students in Ankpa education zone of Kogi state in particular is a deviation from what the real meaning of patriotism depicted to be. This the researcher assumed to be the ill performance on the part of school management especially on the proper functioning of guidance and counselling unit of the school leading to a deterioration in the practice of patriotism by the students in most of their dealings. Based on this, the need to investigate the extent of influence guidance and counselling service had on college of education students' level of patriotism in Ankpa education zone has become imperative.

Management is an essential aspect of educational system because they are the decider of the policy for the institution. Management of College of education include governing
Council, Provost, Deputy Provost, Registrar, Bursar, College Librarian and Director of Works respectively. They are mostly principal officers of the college. Other members though extended management include academic board members which include Principal Officer, Deans of Schools, Vice Deans of Schools, Chief Lecturers, Principal Lecturers, Representatives of the Congregation and Heads of Department. They perform the following functions such as Planning, Organizing, Staffing, Leading, Controlling (Krishna, 2006). Management as a body carryout and promotes the effectiveness of these functions for the attainment of educational objectives of college of education.

College of education is one of the tripods of tertiary education in Nigeria. It is a tertiary institution which prepares students for a period of three years qualifying them to teach in primary, junior secondary schools and technical colleges. It has the primary role of training teachers who will be awarded the teaching qualification of Nigerian Certificate in Education (NCE) (Gabriel \& Fehintola, 2011). A college of education in this context is therefore a tertiary institution of learning which provides specialized professional or vocational training for individuals who will later become teachers.

Colleges of education in Ankpa education zone of Kogi stateNigeria are selected owing to the observation of Shaibu (2016) that mismanagement of guidance and counselling services for students level of patriotism and strict adherence to societal values in the areas seem to be on the high side in the Colleges of Education in the zone which resulting in deterioration of values especially an increase in crime wave, practice of prostitution, indecent dressing, lawlessness, kidnapping, armed robbery, assassination, lies, examination malpractice, etc. Therefore, management factors which affect guidance and counselling services delivery in colleges of education, Ankpa education zone need to be investigated.

Ankpa education zone comprises of Ankpa, Olamaboro and Omala Local Government Areas of Kogi State. The area has four colleges of education namely, Kogi State of College of Education, Ankpa, Al-Hikmah College of Education, Ankpa, Peace College of Education, Ankpa and Omala College of Education, Abejukolo. Colleges of Education in this zone are still at the baby stage except Kogi State College of Education, Ankpa and majorly characterised with few and old buildings and guidance and counselling services in these colleges are observed to be poorly rendered to the students. Besides, students of these colleges are poorly mobilized for the services in the observation of researchers by the management making them to have poor perception about the importance of guidance and counselling services in their schools. The choice of Ankpa education zone of Kogi state for the study is due to the urgent need by government to stimulate students' interest in guidance and counselling services as it is vital to their level of patriotism and adherence to the practice of values system in schools.

The effectiveness of managers in the colleges of education is a function of the competence of heads of the various departments, sections and units in terms of initiative towards proper discharging of duties/responsibilities accrued to them. To this end, managers at the various levels are expected to acquire relevant training in the field of management through attending seminars, workshops and conferences towards enhancing their competence. Failure of 
the school management to provide these opportunities in quantity and quality will lead to poor staff and students' effectiveness and poor level of patriotism and adherence to the practice of values in COE (Arugbeyi, 2009). It is in line with this that Adegbesan (2010) observed that the Colleges of Education cannot accomplish their tasks without the backup of relevant and functional educational training and sound guidance and counselling services which are the management responsibilities to provide. Hence, the National Commission for Colleges of Education (NCCE, 2012) mandated all the Colleges of Education to have functional guidance and counselling unit in order to influence students' level of patriotism and adherence to the practice of the societal values as school is not only to inculcate knowledge but also the right type of values in the children as well as preservation of culture. However, the basis for the worry in this study is to ascertain how the guidance and counselling services are been managed in colleges of education to influence the students' level of patriotism and their adherence to value practices in Ankpa education zone of Kogi state.

\section{Statement of the problem}

Over the years, colleges of education students' level of patriotism and adherence to the practice of values in Nigeria especially Ankpa education zone seems to have been perplexed with management factors such as under staffing of the guidance and counselling department, overloading of a guidance and counselling staff with too many teaching periods outside their areas of specialization, poor remuneration of the guidance and counselling personnel, poor quality of counselling facilities, employment of mediocre amongst others without any palpable effort to stabilize them even in the deteriorating level of these variables.

It has been observed by Shaibu that colleges of education in Ankpa education zone of Kogi states appear generally illequipped for administration of guidance and counselling services to the students making their level of patriotism and adherence to the practice of value to be doubtful. For instance, there are inadequate good seats for students during counselling especially if it involves few populations, which make the counselling room to be overcrowded. The standard for counselling space is not maintained; most of the counselling staff offices are obsolete; to the extent that most of the staff are exposed to danger in the offices. The facilities that could facilitate counselling services are few and office equipment used to prepare counselling activities and programmes are mostly outdated.

Besides, they use of non-professionals in guidance and counselling services as a result of inadequate counsellors; poor utilization of ICTs in guidance and counselling services; inadequate continuous staff training and development; inadequate time allocated to counselling services; shortage of facilities and equipment for guidance and counselling services, lack of effective use of other evaluation services through Computer Assisted Testing system (CAT); negligence on the part of parents; inadequate and lack of consistency in the use of orientation service and diagnostic and appraisal service by counsellors; and inadequate staff training and development programmes for school counsellors are all observed to affect the colleges of education students' level of patriotism and adherence to the practice of values in Ankpa education zone of Kogi state.
However, the problem of the study put in question form is, how can guidance and counselling services be managed for patriotism and values rejuvenation among students of colleges of education in Ankpa education zone of Kogi state?

\section{Purpose of the Study}

The general purpose of the study is to investigate managing guidance and counselling services for patriotism and values rejuvenation among the students of colleges of education in Ankpa education zone of Kogi state. Specifically, the study seeks to:

1. Find out whether the management of guidance and counselling services has any significant influence on students' level of patriotism in colleges of education in Ankpa education zone of Kogi state.

2. Ascertain whether the management of guidance and counselling services has any significant influence on students' level of values' practices in colleges of education in Ankpa education zone of Kogi state.

\section{Research Questions}

1. How does management of guidance and/counselling services influence students' level of patriotism in colleges of education in Ankpa education zone of Kogi state

2. To what extent do management of guidance/and counselling services influence students' level of values' practices in colleges of education in Ankpa education zone of Kogi state?

\section{Methods}

The study adopted an ex-post facto research design. The study meets the requirement for ex-post facto design because the researcher is only studying and observing students' level of patriotism and adherence to the practice of values as relate to management of guidance and counselling services. The population of the study comprised of all the four (4) colleges of education in Ankpa education zone of Kogi State with 25,060 students that serves as respondents. Reason for the choice of this population was based on the fact that these respondents are directly the bearers of guidance/counselling services that influence their level of patriotism and the practice of values in colleges of education and the entirety of their of society. The sample for the study was 250 NCE students randomly selected for the study from the four colleges of education. The choice of NCE students was due to the fact that the degeneration of societal values is more prominent among them in the area.

The instruments used for the study is Students' Patriotism and Values Adherence Level Parameter (SPLP) and Students Values Adherence Parameter (SVAP). SPLP contains 10 items structured in four point options of Strongly Agree, Agree, Disagree and Strongly Disagree while SVAP contains 10 items structured in four point options of Very High Extent (VHE), High Extent (HE), Little Extent (LE) and Very Little Extent (VLE). The items were generated on the basis of managing guidance and counseling services for patriotism and values rejuvenation among the students of colleges of education in Ankpa education zone of Kogi state. These items were administered on selected NCE three students who were observed with degeneration of values and patriotism in the area. Students' Patriotism and Values Adherence Level Parameter (SPLP) and Students Values Adherence Parameter (SVAP) were subjected to validation by three experts in the field of education: two experts from 
measurement and evaluation and one from Educational Foundations Departments. These lecturers are all from Kogi State University Anyigba in order to establish face and content validity of the instrument. The re-adjustment of the items was done by the experts to make them intelligent and constructive. To ensure the reliability of the instrument the SPLP and SVAP was subjected to a study where the questionnaires were administered to 30 students from FCE Okene-Kogi state and Peace Land college of Education, Enugu state, Ankpa study centre in areas that are not part of the study. The responses were estimated using cronbach alpha correlation coefficient method and it yielded 0.76 and 0.82 indicating that the instruments were $76 \%$ and $82 \%$ reliable for use. Analysis of research questions that guided the study was done by mean and standard deviation.
In the analysis of research questions, responses with mean of 0.50-1.49 were rated Very Little Extent (VLE) and Strongly Disagree (SD). Responses with mean of 1.50 - 2.49 were rated Little Extent (LE) and Disagree (D). Responses with mean of 2.50-3.49 were rated High Extent (HE) and Agree (A). Responses with mean of 3.50-4.00 were rated Very High Extent (VHE) and Strongly Agree (SA) respectively.

\section{Results and Discussion}

This section deals with interpretation and discussion of findings. The data collected using the instrument developed for the study were presented and analyzed using mean and standard deviation to answer research questions that guided the study. Interpretation of the analyzed data was also done.

\section{Research Questions}

1. How does management of guidance and counselling services influence students' level of patriotism in colleges of education in Ankpa education zone of Kogi state?

\section{Table 1: Influence of Management of Guidance and Counselling on Students Level of Patriotism in Colleges of} Education

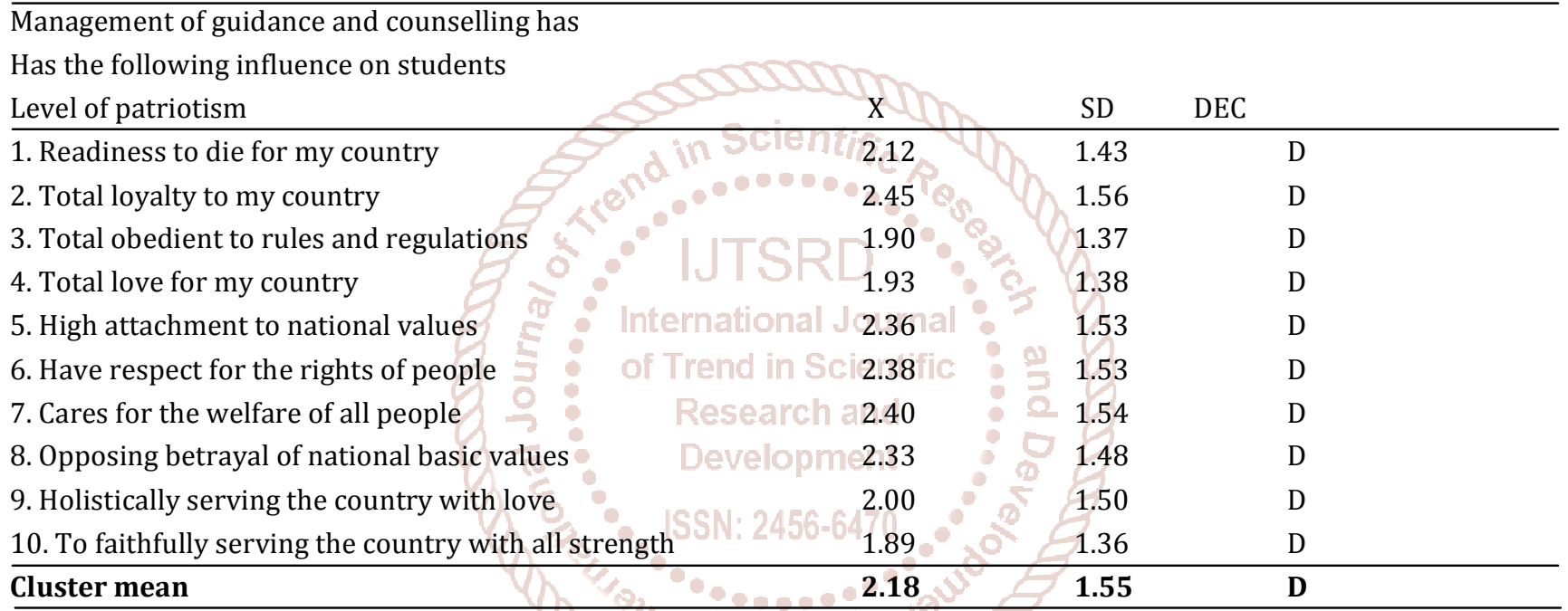

\section{Key: Strongly Agree (SA), Agree (A), Disagree (D), Strongly Disagree (SD)}

Data presented on Table 1 showed the mean and standard deviations of influence of management of guidance and counselling services on students' level of patriotism in colleges of education in Ankpa education zone.

Items $1,2,3,4,5,6,7,8,9$ and 10 were rated by students as 2.12 with standard deviation of $1.43,2.45$ with standard deviation of $1.56,1.90$ with standard deviation of $1.37,1.93$ with standard deviation of $1.38,2.36$ with standard deviation of $1.53,2.40$ with standard deviation of $1.54,2.33$ with standard deviation of $1.48,2.00$ with standard deviation of 1.50 and 1.89 with standard deviation of 1.36 respectively. Based on the data analysis, it was revealed that Readiness to die for my country, Total loyalty to my country, Total obedient to rules and regulations, Have respect for the rights of people, Total love for my country, High attachment to national values, Cares for the welfare of all people, Opposing betrayal of national basic values, Holistically serving the country with love, To faithfully serving the country with all strength were disagreed by students as influence of management of guidance and counselling on students level of patriotism in Kogi east education zone. Based on the data analysis, it was revealed that by students mean ratings that management of guidance and counselling services does not influence college of education students' level of patriotism in Ankpa education zone. This finding disagreed with the finding of Oguzie (2014) who carried a research on guidance and counselling services as a coping strategy for inculcating the consciousness of peace, conflict resolution and national security- an elements of patriotism among secondary school youths in Anambra state, Nigeria and found out that guidance and counselling services when effectively utilized could be used to inculcate in the youths' such consciousness that enhanced peace, conflict resolution and national security which are the elements of patriotism.

2. To what extent do management of guidance/and counselling services influence students' level of values' practices in colleges of education in Ankpa education zone of Kogi state? 
Table 2: Extent of Influence Management of Guidance and Counseling Had on Students Level of Values' Practices in Colleges of Education

\begin{tabular}{llll}
\hline Items on extent of influence of management of guidance & & & \\
And counselling on students level values' practices & $\mathrm{X}$ & $\mathrm{SD}$ & Decision \\
\hline 11. Respect and honour accorded to parents & 1.73 & 0.74 & $\mathrm{LE}$ \\
12. Love of the family & 1.28 & 0.70 & VLE \\
13. Protection of the family name & 1.66 & 0.59 & $\mathrm{LE}$ \\
14. Respect for people in the position of authority & 1.31 & 0.56 & VLE \\
15. Maintenance of integrity & 1.71 & 0.58 & LE \\
16. Transparency & 1.20 & 0.51 & VLE \\
17. Responsibility & 1.46 & 0.64 & LE \\
18. Accountability & 1.41 & 0.61 & VLE \\
19. Fairness & 1.61 & 0.60 & LE \\
20. Equity & 1.42 & 0.58 & VLE \\
\hline Cluster mean & $\mathbf{1 . 7 7}$ & $\mathbf{0 . 1 9}$ & LE \\
\hline
\end{tabular}

Key: Very High Extent (VHE), High Extent (HE), Little Extent (LE), Very Little Extent (VLE).

Data presented on Table 2 above showed the mean ratings and standard deviations of students on extent of influence management of guidance and counseling had on students' level of values' practices in colleges of education in Ankpa education zone of Kogi state.

Items $11,13,15,17$ and 19 were rated by students as 1.73 with standard deviation of $0.74,1.66$ with standard deviation of $0.59,1.71$ with standard deviation of $0.58,1.48$ with standard deviation of 0.60 and 1.61 with standard deviation of 0.60 respectively. Based on the data analysis, it was revealed that Respect and honour accorded to parents, protection of the family name, maintenance of integrity, responsibility and ffairness were practiced by students to a little extent in Kogi east education zone of Kogi state.

Items $12,14,16,18$ and 20 were also rated by lecturers as 1.28 with standard deviation of $0.70,1.31$ with standard deviation of $0.56,1.20$ with standard deviation of $0.51,1.41$ with standard deviation of 0.61 and 1.42 with standard deviation of 0.58 respectively. Based on the analyzed data, it was revealed that Love of the family, Respect for people in the position of authority, Transparency, Accountability and Equity were practiced by students to a very little extent in colleges of education in Ankpa education zone of Kogi state. This finding is in contrary to the finding of Pamela et al. (2018) who found out that there is a correlation coefficient of 0.503 between guidance and counselling and management of students' behaviour in schools. But this finding is in consonance with Chikwature and Oyedele (2016) study in Zimbabwe who argues that teachers do not possess the qualifications needed in carrying out guidance and counselling sessions, just as Kirangari (2014) study in Kenya agrees that guidance and counselling programs do not solve all cases of indiscipline in schools which affect students' level of adherence to societal values.

\section{Conclusion}

From the foregoing, it has been deduced that that guidance/counselling services does not influence students' level of patriotism in colleges of education in Ankpa education zone of Kogi state. The paper also revealed that management of guidance/counselling services influence colleges of education students' in the practice of the societal values in Ankpa education zone of Kogi state to a little extent.

\section{Recommendations}

The following recommendations are highlighted based on the conclusion made in this study:

1. Employment of guidance/counsellor should be based on professional to enhance technicality in the administration of the unit in school. This will assist in the overall growth and development of patriotism and strict adherence to practice of Nigerian values among students of colleges of education in Kogi east education zone.

2. Guidance and counselling facilities should be sufficiently provided by the government to all the colleges of education in Kogi east education zone. This will enable staff to be effective in the delivery of services to the students.

3. The available guidance and counselling facilities should be properly managed by the school management, staff and students to ensure its consistent functionality. Proper management of these facilities will ensure their durability for the benefit of the clients.

4. Conferences, seminars, workshop, symposium amongst others should always be organized by the government for both students and staff on the importance of guidance and counselling for students level of patriotism and adherence to the practice of values of the society. This will expose them to the learning of such values for sustenance of society.

5. There should be proliferation of guidance and counselling centres everywhere in Kogi state by the government. This will enable every member of the area to have access to $\mathrm{G} / \mathrm{C}$ centres in time of need.

\section{REFERENCES}

[1] Adebesan,S.O.(2010). Establishing quality assurance in Nigeria's education management. Education Research and Reviews 5 (7), 380-384 Retrieved august 20, 2010 from $h t t: / / w w w . a c a d e m i c ~ J o u r n a l s . ~ O r g / e r r 2$

[2] Adeyemi, A. A. (2016). Curbing corruption practices through vocational training programme and correct value re-orientation in Nigeria. Journal of National Association of Women in Colleges of Education..21 (2):11-119.

[3] Adzemba, P. S. (2006). Introduction to school management and supervision. Makurdi: Chico Press. 
[4] Afande, 0. (2015). Effects of Guidance and Counseling on Pupils in Public Primary Schools in Makadara Primary Schools in Makadara Division of Nairobi Province. Research on Humanities and Social Sciences Vol. (5) Pp.63-77.

[5] Agu, L.A. The place of guidance and counseling in value reorientation and behavior modification among Nigerian youths. Journal of National Association of Women in Colleges of Education. 2016; Vol. 21(2), 64-67.

[6] Aishtu, M. U. \& Lucy, U. S. (2016). Family value reorientation in curbing corruption in Nigeria. Journal of National Association of Women in Colleges of Education. 21(2):82-85.

[7] Akpakwu, S.O. (2008). Essential of educational management. Makurdi: Jalim Press.

[8] Arugbeyi, D.O. (2009). Lecture quantity and gender in College of Education in Nigeria College student, Journal find article.com. 10 Oct. 2010.

[9] Baba'atu, H. G. (2016). Effect of corruption in Nigerian politics and the need for value re-orientation. Journal of National Association of Women in Colleges of Education. 21, (2)1-4.

[10] Beatrice, H. A. (2016). Enhancing ICT towards value reorientation for curbing corruption in the country. Journal of National Association of Women in Colleges of Education. 21(2): 125-127

[11] Chikwature, W. \& Oyedele, V. (2016). Effects of Deviant Behaviour on Academic Performance in Mutare Urban Primary Schools in Mutare Districts. European Journal of Psychological Research. Vol. 3 No.1.pp 35-45.

[12] Denga, D. I. (2001). Guidance and Counselling in School and Non- School Settings. 2nd Ed. Port - Harcourt: Double Diamond Publications.

[13] Egbule, J. F. (2006). Guidance Services. In O. C. Okobiah \& R. I. Okorodudu (Editors) Issues, Concepts, Theories and Techniques of Guidance and Counselling. Benin-City: Ethiope Publishers, 76 - 110.

[14] Esen, A. J. A. (1998). Guidance and Counselling for SocioPolitical Stability in Nigeria. An Inaugural lecture delivered at the University of Uyo on 29th of April, 1998.

[15] FRN [Federal Republic of Nigeria] (2004). National Policy on Education. 4th Edition. Lagos: NERDC Press, pp. $10-11$.

[16] Gabriel, 0.O. \& Fehintola, N.O. (2011). Staffing patterns of state college of education libraries in Nigeria, Retrieved. May, 10, 2013 from http://um/lib.unl.edu/lpp/.

[17] Godiya, D. G. (2016). English language and literature: Viable tools for achieving value re- orientation in Nigeria. Journal of National Association of Women in Colleges of Education. 21(2): 120-124.

[18] Kateb, George. 2006. Patriotism and Other Mistakes. New Haven, Connecticut: Yale UP.

[19] Kirangari, T. (2014). Effectiveness of Guidance and Counseling in Managing Students' Discipline in public secondary schools in Kandara District, Murang'a. Unpublished Med. Project, Kenyatta University.
[20] Krieger, N. (2013).Errorless Classroom management for students with severe conduct problems: A staff training approach. Unpublished Phd Thesis. University of Toronto. International Journal of Applied Psychology 2018, 8(1): 6-11 11

[21] Krishna, K. S. (2006). Modern Concept of Management. Available

at: www.sgnhc.org.np/.../MODERN\%20CONCEPT\%200F\%2 OMANAGEM... [Accessed 25 April, 2018]

[22] Modo, F. N. \& Inaja, A. E. (2010). Rebranding Skills for Counsellors toward Curbing Personal- Social Problems in the School System. Ibom Journal of Counselling 1(1), 40 - 46.

[23] Modo, F.; Sanni, K.; Uwah, C. \& Mogbo, I. (2013). Guidance and Counseling Services in Secondary School as Coping Strategy for Improved Academic Performance of Students in Akwa Ibom State, Nigeria. In Journal of Research on Humanities and Social Sciences, 3 (4), pp.43-47.

[24] Mwangi, J. (2014). Influence of Alternative Disciplinary Measures on Students Discipline in Public Secondary Schools in Laikipia West District, Kenya. Unpublished M.Ed Thesis, University of Nairobi.

[25] National Commission for Colleges of Education (NCCE) (2012). Digest of statistic on colleges of education and other NCE awarding Institutions in Nigeria, Abuja: NCE office.

[26] Nwachuku, D. I. (2007). The Teacher Counsellor for Today's School. Calabar: University of Calabar Press.

[27] Nweze. T \& Okolie, U. (2014). Effective Guidance and Counseling Programs in Secondary Schools: Issues and Roles in Students' Career Decision Making. Journal of Research and Methods in Education. Vol.4, pp 6368.

[28] Odiba, I. A. (2007). Classroom management and organization: The teacher guide, Kaduna: Euneaks Associates.

[29] Oguzie, S. N. (2014). Guidance and Counselling Services as a Coping Strategy for Inculcating the Consciousness of Peace, Conflict Resolution and National Security among Secondary School Youths in Anambra State, Nigeria. An International Multidisciplinary Journal, Ethiopia Vol. 8 (2), Serial No. 33, April, 2014:256-279

[30] Okobiah, O. C. \& Okorodudu, R. I. (2006). Concepts of guidance and counselling. In O. C. Okobiah and R. I. Okorodudu (Eds.) Issues Concepts, Theories and Techniques of Guidance and Counselling. Benin-City: Ethiopie Publishers, 24 - 54.

[31] Osakwe, R (2013). Principal's Mnagement Techniques for resolving Disciplinary problems in Nigerian public Secondary schools. Journal of Education and Practice. Vol. 4, pp.50-57.

[32] Pamela, A. O., Peter, J. A., Pamela. R. (2018). Effectiveness of Guidance and Counselling in the anagement of Student Behaviour in Public Secondary Schools in Kenya International Journal of Applied Psychology 2018, 8(1): 6-11. 
[33] Renuka, D. (2013). Effect of Counseling on the Academic Performance of College Students. Journalof Clinical and Diagnostic Research (7) pp.1086-1088.

[34] Sekiwu, D. \& Naluwemba, F. (2014). Alternatives to Instilling Discipline in Primary Schools during the Post Corporal Punishment Era in Uganda. Global Journal of Human-Social Science,Vol. 14, Issue 4, pgs 16-24.

[35] Shaibu, L. (2016). Management of school facilities for effective instructional delivery in colleges of education north central states of Nigeria. Unpublished Thesis, Faculty of Education, University of Nigeria, Nsukka.

[36] Staub, E. (1997). "Blind versus Constructive Patriotism: Moving From Embeddedness in the Group to Critical
Loyalty and Action." In Daniel Bar-Tal and Ervin Staub, eds. Patriotism: In the lives of individuals and nations. Chicago: Nelson-Hall.

[37] Ugwuegbulem, C. N. \& Igbokwe, O. O. (1996). Dimensions of guidance and counselling of guidance and counselling. In F. J. Nwachukwu and C. N. Ugwuegbulem Guidance and Counselling on Introductory Survey. Benin-City: Barloz Publishers, 24 49.

[38] Umar, H. (2013). The Need for Peace Education in Nigerian Secondary School Curriculum. Nigerian Journal of Educational Philosophy -NJEP. Peace Education, 24 (1), 41-51. Published by Philosophy of Education Association of Nigeria (PEAN). 